\title{
PERANCANGAN PERPUSTAKAAN UMUM DAERAH TANGERANG SELATAN DENGAN PENDEKATAN ALIRAN ARSITEKTUR DE STJIL
}

\author{
Muchsin Nugrahanto ${ }^{1}$, Atie Ernawati ${ }^{2}$, Ryan Hidayat ${ }^{3}$ \\ ${ }^{1}$ Universitas Indraprasta PGRI, Program Studi Arsitektur \\ muchsin.mn@gmail.com \\ ${ }^{2}$ Universitas Indraprasta PGRI, Program Studi Arsitektur \\ atie.ernawati@unindra.ac.id \\ ${ }^{3}$ Universitas Indraprasta PGRI, Program Studi Arsitektur \\ ryansastra3@gmail.com
}

\begin{abstract}
South Tangerang City is the result of the expansion of the city of Tangerang, which still needs facilities and infrastructure to support the knowledge of the area. There needs to be awareness of the people of South Tangerang regarding the importance of public libraries to increase reading interest so that they can absorb knowledge and improve the quality of the community in South Tangerang. Designing public library buildings using a modern architectural approach is expected that the community can be interested and then grow their sense of wanting to read books in the library. De Stjil as the concept of design is expressed in pure forms, which means the purity contained in the book in the library. From this characteristic, it can be harmonized with the shape of the book, which is geometric.
\end{abstract}

Key Words: South Tangerang, public library, de stjil

\begin{abstract}
Abstrak. Kota Tangerang Selatan merupakan hasil pemekaran dari kota Tangerang yang masih memerlukan sarana dan prasarana untuk menunjang ilmu pengetahuan daerah tersebut. Perlu adanya kesadaran terhadap masyarakat Tangerang Selatan mengenai pentingnya perpustakaan umum untuk meningkatkan minat baca sehingga dapat menyerap pengetahuan dan meningkatkan kualitas masyarakat daerah Tangerang Selatan. Merancang bangunan perpustakaan umum dengan menggunakan pendekatan arsitektur modern diharapkan masyarakat dapat tertarik kemudian tumbuh rasa ingin membaca buku di dalam perpustakaan. De stjil sebagai konsep rancangan diungkapkan dalam bentuk-bentuk murni, yang berarti kemurnian yang terkandung pada buku di dalam perpustakaan tersebut. Dari ciri de stjil tersebut dapat di selaraskan dengan bentukan buku yaitu geometris.
\end{abstract}

Kata Kunci : Tangerang Selatan, perpustakaan umum, de stjil

\section{PENDAHULUAN}

Mencari latar belakang untuk dijadikan topik atau Issue sebuah rancangan dengan permasalaah dan kebutuhan pengunjung yang akan di kembangkan menjadi rancangan dan ide desain bangunan perpustakaan umum dan public space agar meningkatkan minat baca masyarakat daerah Tangerang Selatan dengan menggunakan tema de stjil aliran arsitektur modern.

Kondisi kantor dinas perpustakaan dan arsip Tangerang Selatan yang sudah terlihat tidak terawat, hal tersebut dapat dilihat dari perpustakaan umum dibelakangnya tidak terlihat seperti perpustakaan melainkan seperti ruko, dan tidak ada penanda jika bangunan tersebut adalah perpustakaan umum.
Seiring dengan itu, minat baca masyarakat yang semakin lama semakin rendah di kota Tangerang Selatan hanya 0,001 persen (bantenhits.com), sehingga perpustakaan menjadi sepi pengunjung, hal ini disebabkan karena fasilitas perpustakaan tidak mewadahi sebagai pusat informasi, dan bangunan yang tidak menarik perhatian, dan akses yang sulit terjangkau oleh masyarakat. 


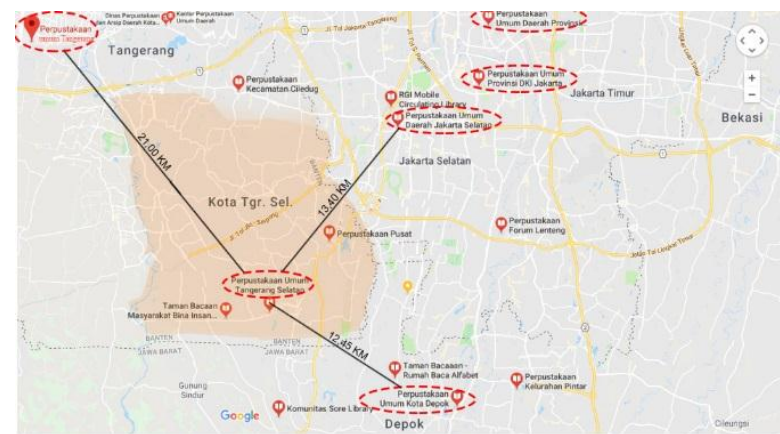

Gambar 1. Mapping Perpustakaan Umum Daerah

a. perpustakaan umum daerah provinsi $( \pm 21,61$ $\mathrm{km})$

b. perpustakaan umum provinsi DKI Jakarta $( \pm 18,50 \mathrm{~km})$

c. perpustakaan umum daerah Jakarta Selatan $( \pm 13,40 \mathrm{~km})$

d. perpustakaan umum kota Depok $( \pm 12,45 \mathrm{~km})$

e. perpustakaan umum kota Tangerang $( \pm 21 \mathrm{~km})$

Lokasi Tapak berada di jalan Siliwangi, Benda baru, Pamulang, Pondok Benda Pamulang, kota Tangerang Selatan, Banten, 15417. Pamulang merupakan salah satu kecamatan daerah Tangerang Selatan provinsi Banten.

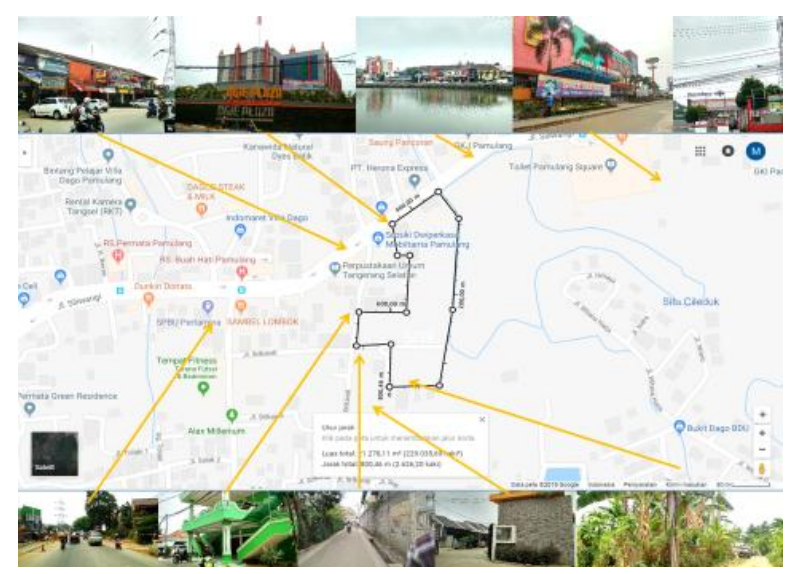

Gambar 2. Kondisi Eksisting Site

Berikut merupakan analisa penulis pada lahan yang ingin dirancang perpustakaan umum :
1. Analisis Pandangan/view

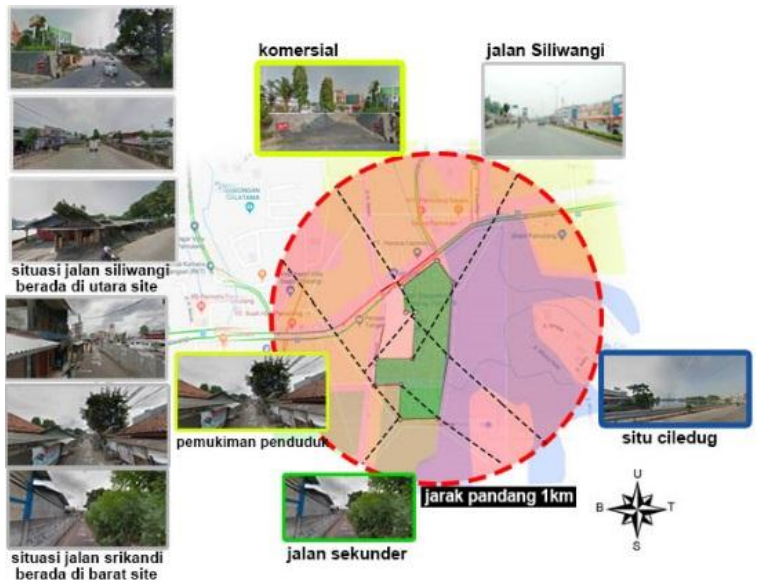

Gambar 3. Pandangan Keluar Tapak

2. Analisis Sirkulasi pada Tapak

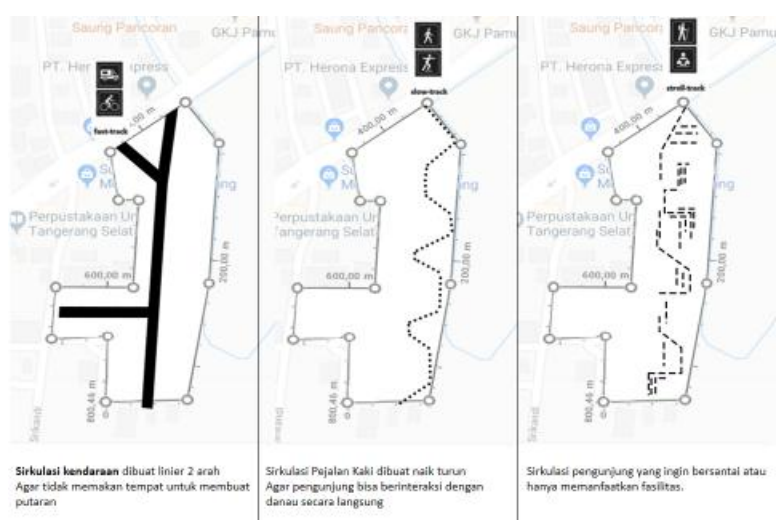

Gambar 4. Konsep Sirkulasi

3. Analisis Cahaya Matahari

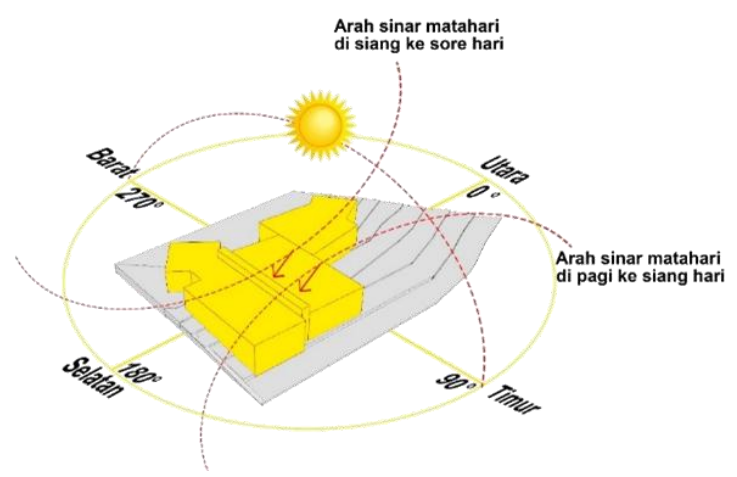

Gambar 5. Analisis Matahari 
(1) Menggunakan elemen alami,

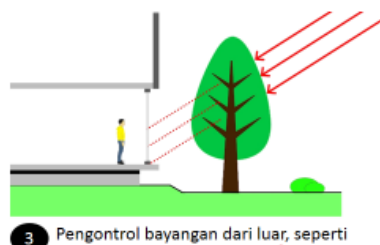
double layer, atau secondary skin

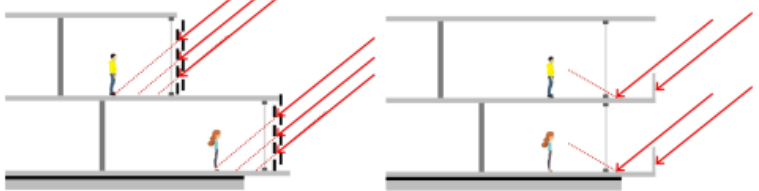

Gambar 6. Strategi dalam Penyelesaian Analisa Matahari

4. Analisis Kebisingan

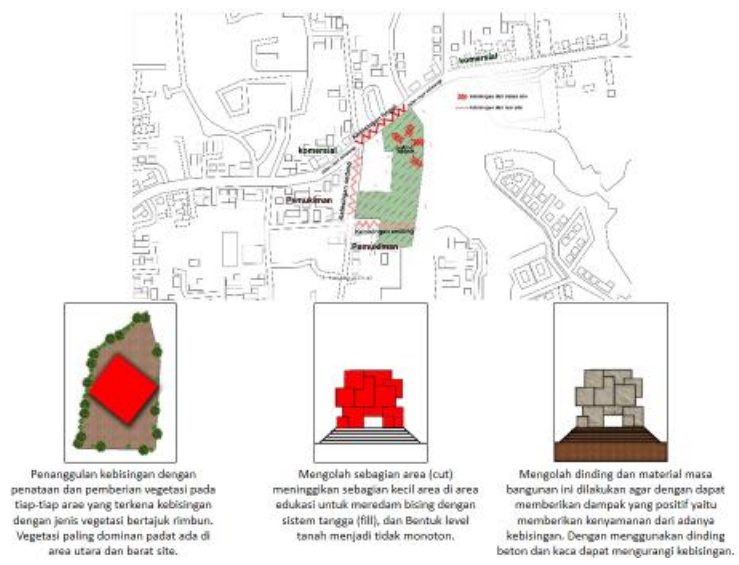

Gambar 7. Analisis Kebisingan

\section{Analisis Penghawaan}

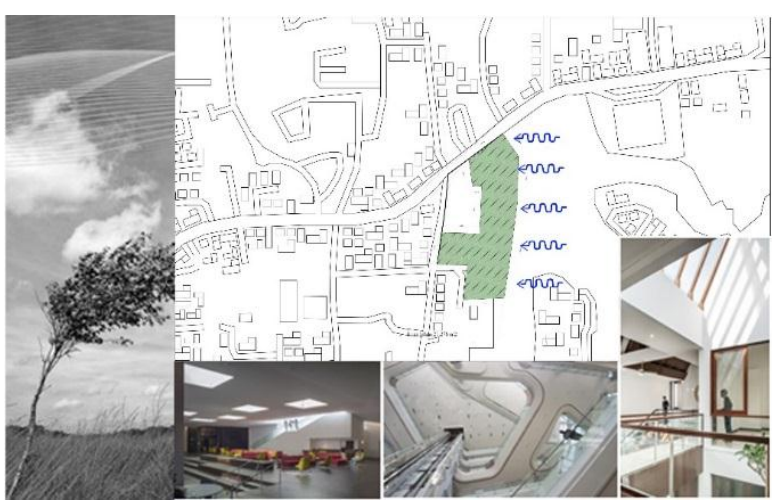

Gambar 8. Analisis Penghawaan
6. Analisis Pencapaian

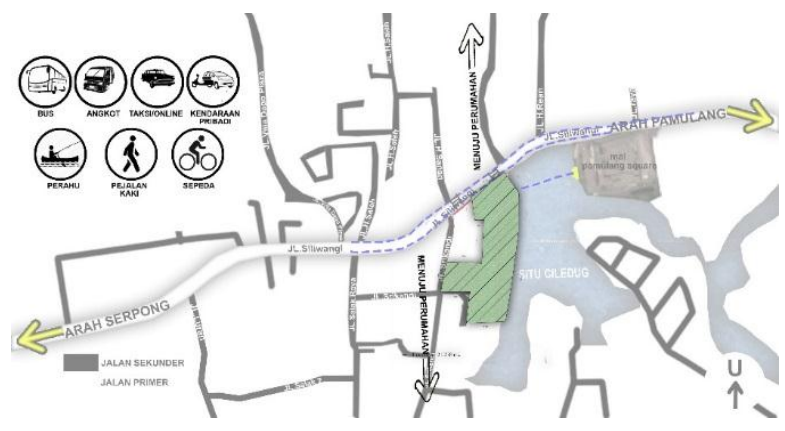

Gambar 9. Analisis Pencapaian Tapak

7. Perhitungan Lahan Terbangun

Peraturan daerah kota tangerang selatan nomor 15 tahun 2011 tentang rencana tata ruang wilayah kota tangerang selatan tahun 2011-2031, BAB VII tentang arahan pengendalian pemanfaatan ruang, paragraf kedua ketentuan umum peraturan zonasi pola ruang, pasal 81 ayat dua adalah ketentuan umum identitas ruang kawasan perdagangan dan jasa sebagaimana dimaksud pada ayat (1) meliputi :

a. KDB maksimal 70 (tujuh puluh) persen.

b. KLB maksimal 8 (delapan)

c. Tinggi bangunan pada blok komersial minimal 3 (tiga) lantai dan maksimal tinggi bangunan sesuai peraturan perundangan KDH minimal 10 (sepuluh) persen.

d. GSB minimal 3 Meter.

e. GSS minimal 30 meter

Jumlah penduduk Kota tangerang selatan pada tahun 2016 sejumlah 1.593 .812 jiwa dengan tingkat pertumbuhan penduduk tiap tahun $3,28 \%$, dengan jumlah anak-anak mencapai 355.296 jiwa dan penduduk dewasa 592.387 jiwa . Dari jumlah penduduk tersebut maka berdasarkan standar Public Library Space Needs untuk kebutuhan tempat duduk (number of seat) digunakan rumus 3 tempat duduk untuk 1000 populasi. Maka jumlah tempat duduk untuk anak-anak disediakan 356 tempat duduk $(355.296 / 1000=355,296=356)$. Untuk dewasa mengunakan standar dalam Planning and Design of Library Building, yaitu 1,5 tempat duduk untuk 1000 populasi, jadi jumlah total tempat duduk sebanyak 656 tempat duduk $(592.387 / 1000) \times 1.5=888,5805=889)$. 
Menurut standar baku perpustakaan pada Data Arsitek, maka untuk melayani penduduk Kota Tangerang Selatan yang mencapai 1.593.812 jiwa (di atas 100.000), maka dibutuhkan jumlah buku koleksi minimal 50.000. Perhitungan besaran ruang berdasarkan hasil analisis dan standar yang telah disesuailkan dengan kebutuhan.

\section{METODOLOGI}

Dalam Perancangan bangunan perpustakaan umum peneliti menggunakan metode pendekatan kualitatif, secara umum metode kualitatif merupakan riset yang bersifat deskriptif dan cenderung menggunakan analisa atas fenomena yang terjadi disertai literatur yang mendukung teori yang di pakai. Peneliti juga menggunakan data kuantitatif, dimana data kuantitatif adalah data yang disajikan dalam bentuk angka-angka.

\section{HASIL DAN PEMBAHASAN}

Kerangka berpikir dari penulis untuk perancangan perpustakaan umum daerah tangerang selatan adalah :

1. Menentukan tujuan dari perpustakaan yaitu :

a. Meningkatkan minat baca masyarakat tangerang selatan untuk semua kalangan dengan memberikan fasilitas yang dapat menarik perhatian masyarakat.

b. Perpustakaan menjadi bangunan yang iconic sehingga dapat menarik perhatian masyarakat.

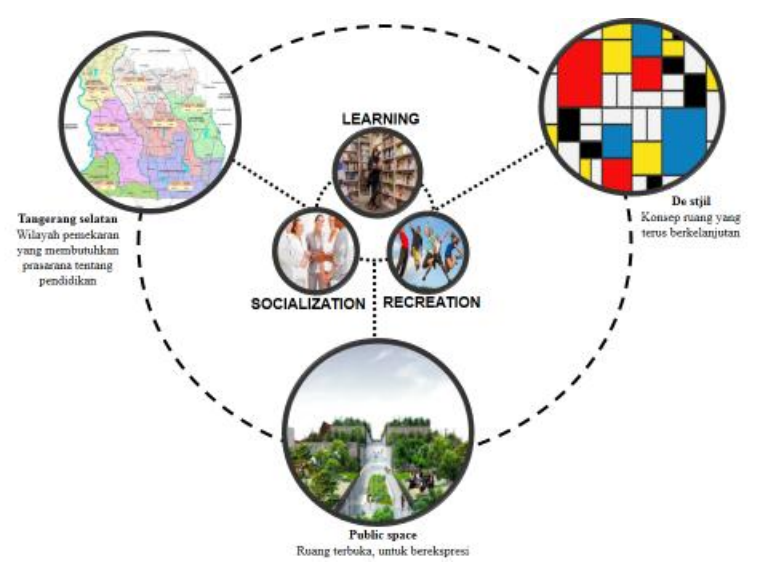

Gambar 10. Kerangka Berpikir Konsep Bangunan

Perancangan bangunan perpustakaan umum menggunakan pendekatan arsitektur modern de stjil. De Stijl diungkapkan dalam bentuk-bentuk murni, yang berarti kemurnian yang terkandung pada buku di dalam perpustakaan tersebut. Dari ciri de stjil tersebut dapat di selaraskan dengan bentukan buku yaitu geometris. Ciri khas warna de stjil yaitu biru, kuning, dan merah membuat suasana menjadi tenang, nyaman, dan menimbulkan rasa kebersamaan.

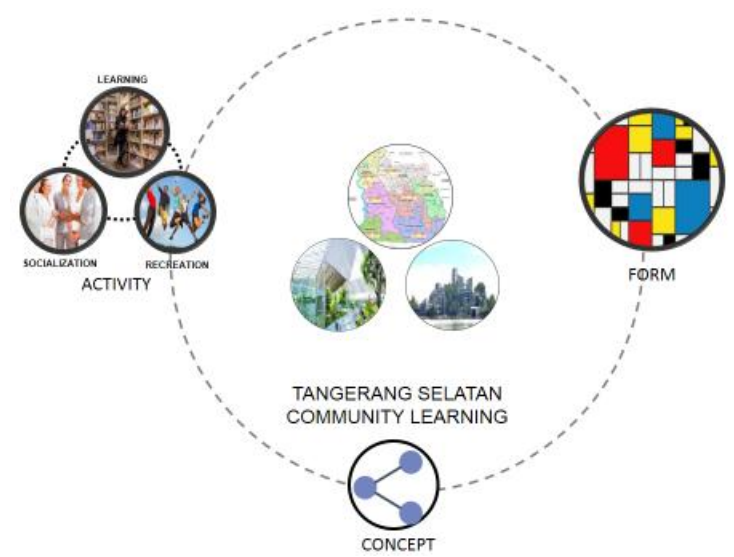

Gambar 11. Kerangka Berpikir Konsep Zoning

Dengan konsep learning, socialization, recreation, perpustakaan dibuat menjadi tiga zona area sesuai fungsi

1. Learning, Tangerang selatan merupakan kota pemekaran yang membutuhkan sarana dan prasarana untuk menambah ilmu pengetahuan baik secara umum maupun formal,

2. Socialization, area sosialisasi yang masih jarang di kawasan tangerang selatan, seperti kegiatan pameran, seminar, bedah buku, dll.

3. Recreation, sebagai daya Tarik pengunjung masuk kedalam site diadakan area rekreasi seperti, amphitheater, public space, area memancing, wisata penyebrangan, promenade dll.

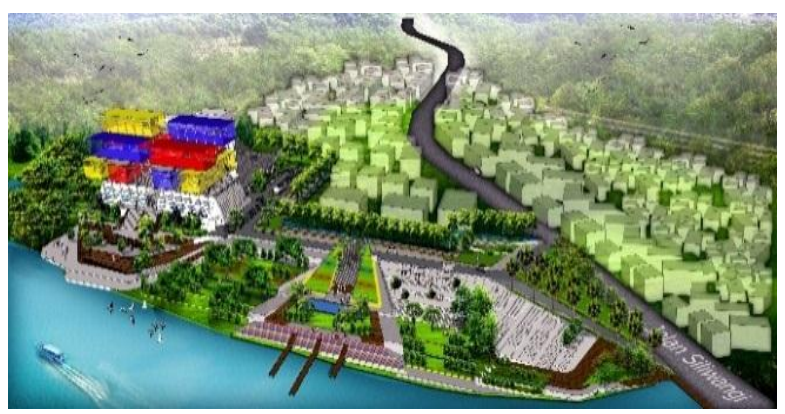

Gambar 12. Plan Bird View 
Perancangan ini dilakukan di Jl. Siliwangi, Pamulang, Kota Tangerang Selatan, Banten 15416, lokasi ini salah satu bagian dari kota satelit penghubung yang mudah di jangkau dari Jakarta menuju Tangerang atau sebaliknya. Lokasi ini juga menyediakan fasilitas penunjang yang lengkap untuk para pengunjung yaitu jalan akses yang dekat menuju tol Jakarta-serpong, kemudian lokasi ini juga berada berdekatan dengan universitas, sekolah menengah atas, sekolah menengah pertama, sekolah dasar, mall, dana pemandangan situ pamulang sehingga memungkinkan potensi penunjang untuk tertarik ke bangunan perpustakaan umum.

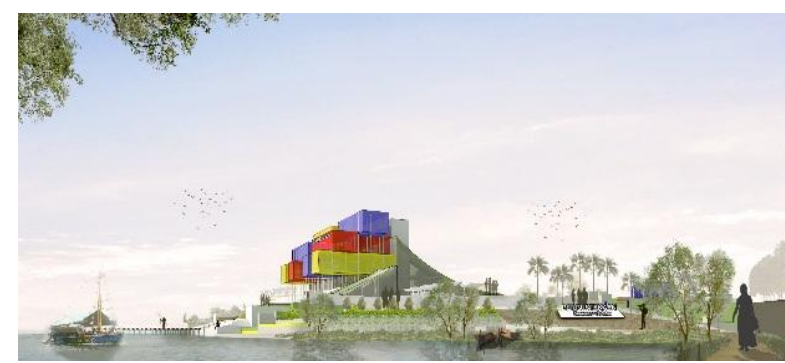

Gambar 13. 3D Perspektif Perpustakaan

\section{Perpustakaan Umum}

Dibangun oleh dana umum dengan tujuan melayani masyarakat umum, dan bersifat terbuka untuk semua dan setiap anggota masyarakat dapat mengakses koleksi.

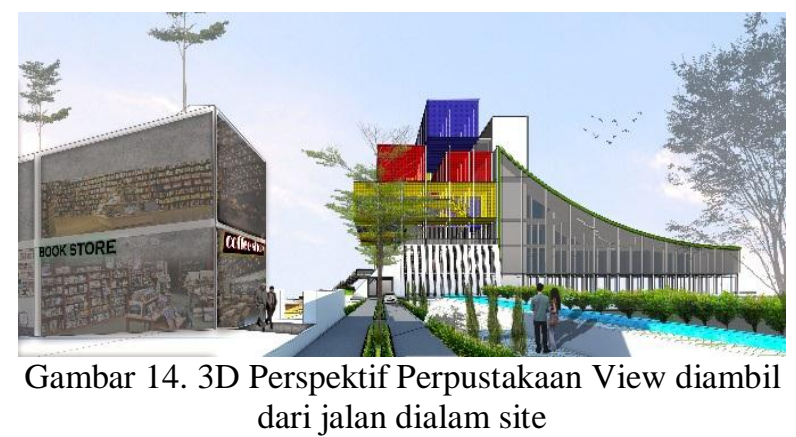

\section{Area penunjang}

Area untuk menunjang bangunan utama atau sebagai fasilitas dari perpustakaan coffe shop dan toko buku sangat berkaitan dengan fungsi utama perpustakaan.

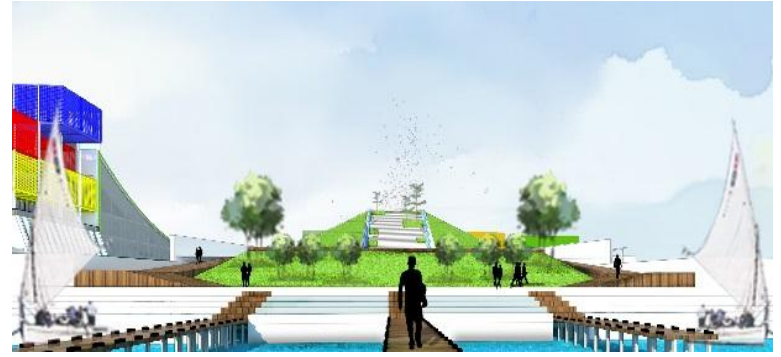

Gambar 15. 3D Perspektif Amphiteater

\section{Amphiteater}

Area Ruang Public digunakan untuk kegiatan bersosialisasi atau ruang ekspresi di area outdoor. Interior perpustakaan

\section{Semi Basemant}

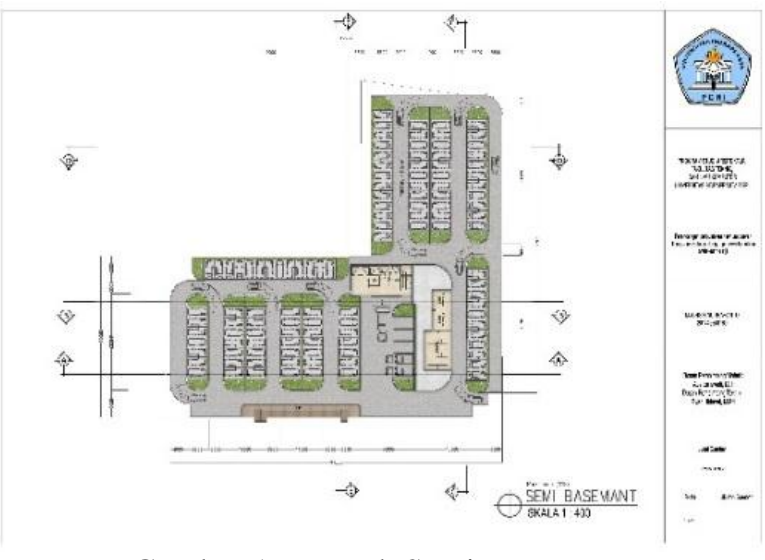

Gambar 16. Denah Semi Basemant

Sebagian besar untuk area parkir mobil dan area service.

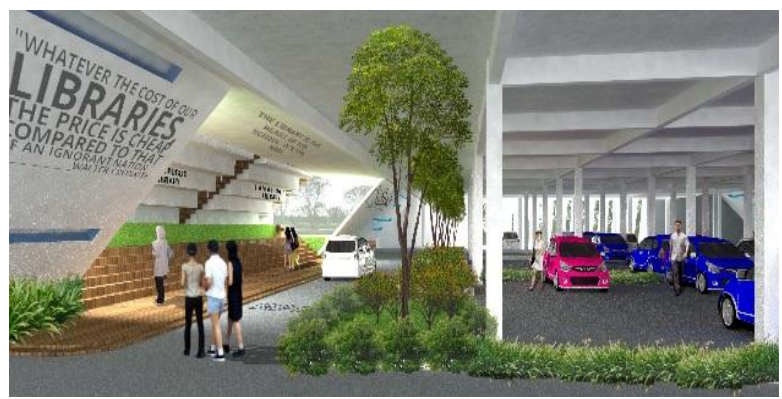

Gambar 17. Perspektif Interior Area Parkir 
2. Denah Lantai 1

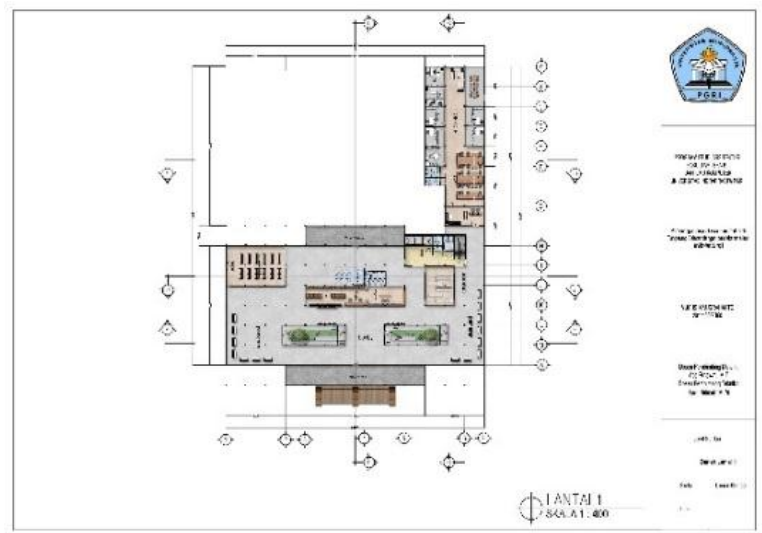

Gambar 18. Denah Lantai 1

Terdapat lobby yang berisi recepsionist untuk pendaftaran, loker, dan ruang koleksi buku langka, serta area pameran dan area kantor arsip.

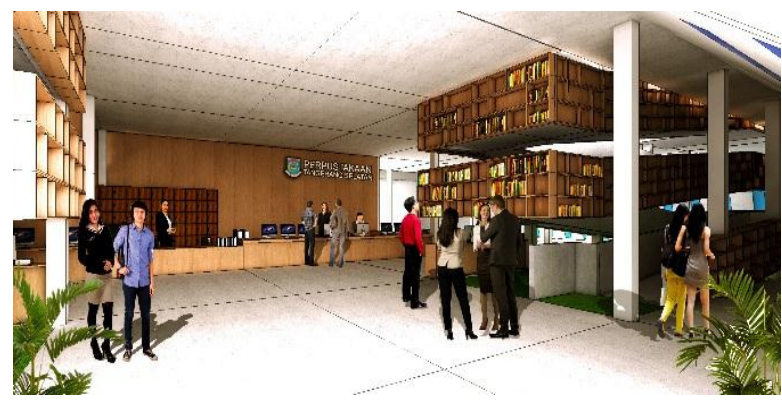

Gambar 19. Perspektif Interior Lobby

3. Denah Lantai 2

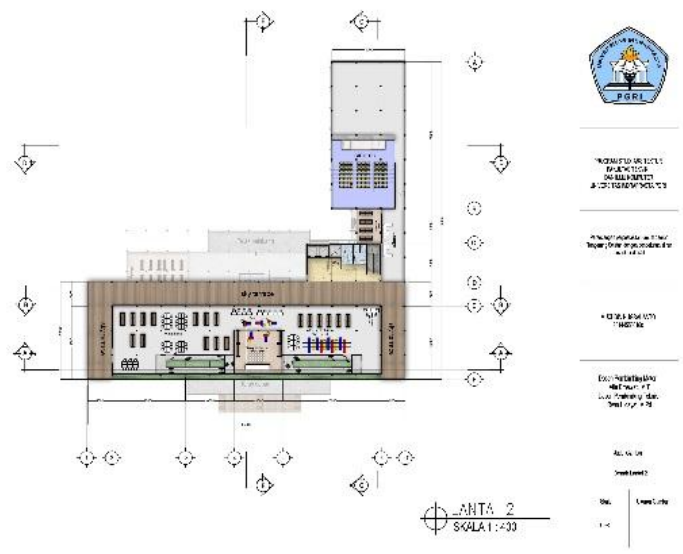

Gambar 20. Denah Lantai 2

Terdapat ruang perpustakaan khusus untuk lansia dan perpustakaan khusus untuk anak-anak, serta terdapat ruang bersama Antara lansia dan anakanak.
4. Denah lantai 3

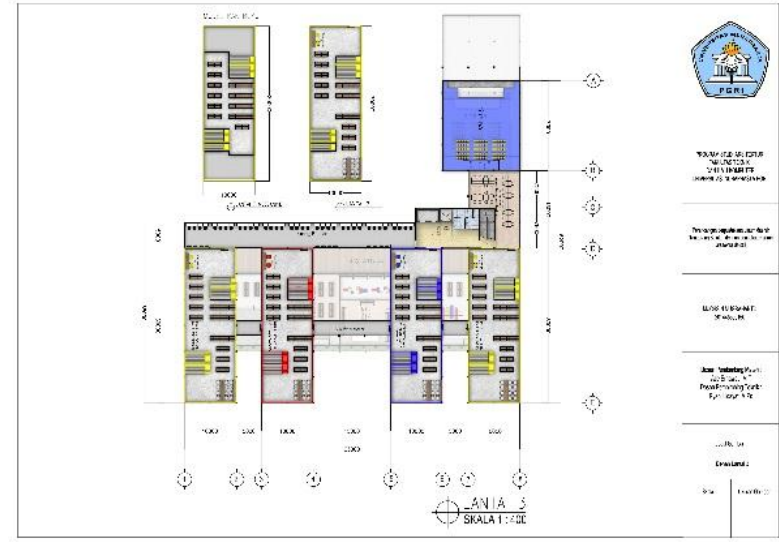

Gambar 21. Denah Lantai 3

Lantai tiga merupakan perpustakaan umum yang berinterior model rak buku satu kotak perpustakaan terdapat kurang lebih 5000 buku. Pada lantai tiga ini terdapat katalog buku yaitu umum, filsafat dan psikologi, agama, dan social, dan ada area penghubung untuk menghubungkan antar kotak.

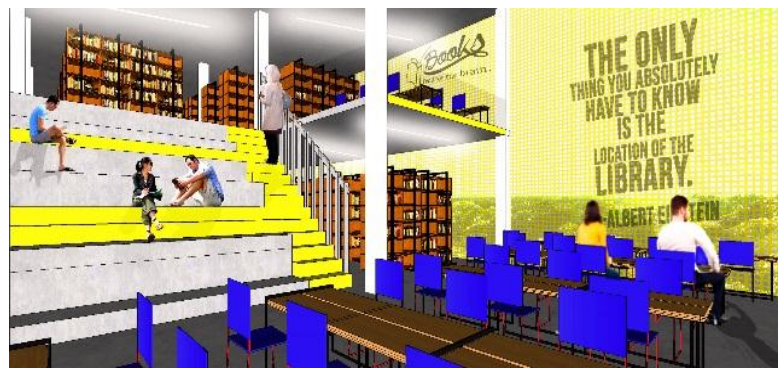

Gambar 22. Perspektif Interior Model rak buku

\section{Denah Lantai 4}

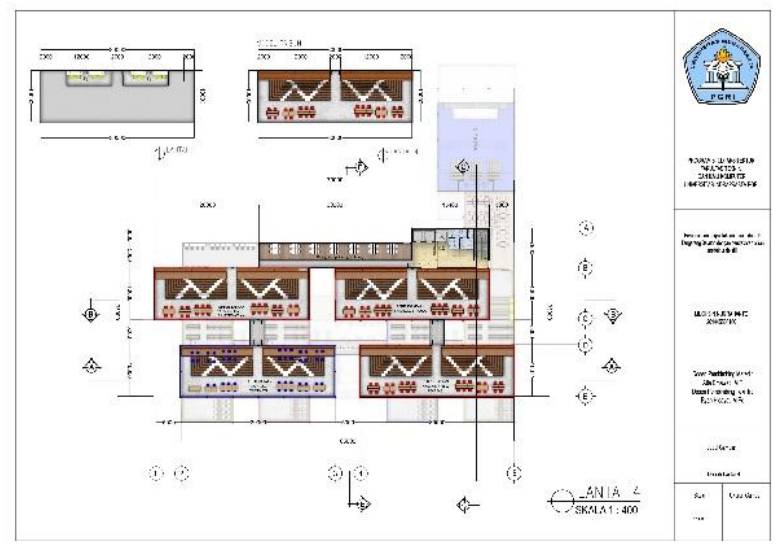

Gambar 23. Denah Lantai 4

Menggunakan interior model tribun, terdapat katalog buku sains dan matematika, bahasa, seni dan rekreasi, teknologi. 


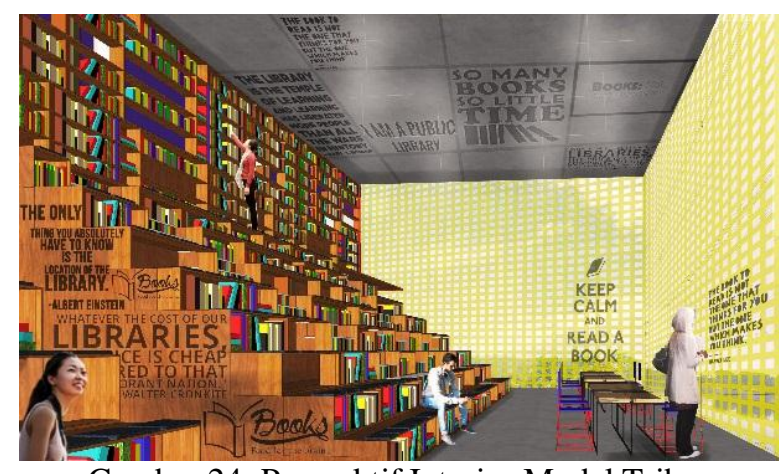

Gambar 24. Perpsektif Interior Model Tribun

6. Denah lantai 5

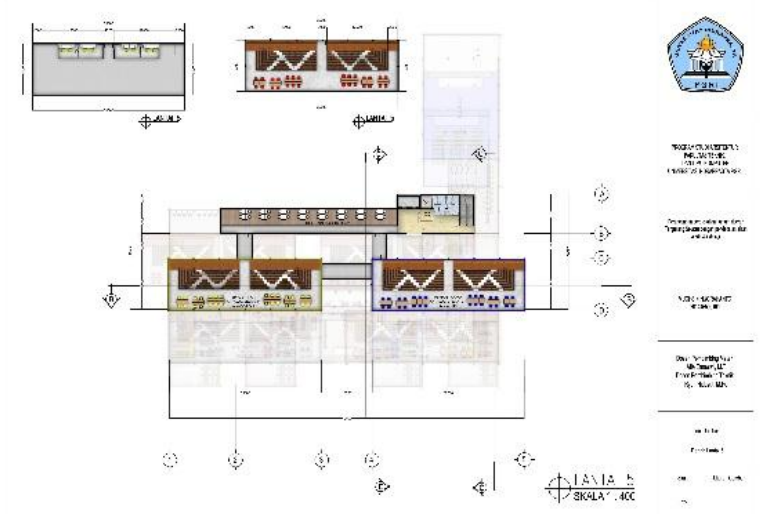

Gambar 25. Perpsektif Interior Model Tribun

Lantai lima sama seperti lantai empat menggunakan interior model tribun dengan katalog buku yaitu sejarah dan geografi, dan literatur dan sastra.

\section{Arsitektur Modern aliran De stjil}

Arsitektur De Stijl merupakan salah satu dari tren atau gaya arsitektur modern yang berkembang pada masa arsitektur modern yaitu antara tahun 1920an sampai dengan tahun 1930an sebelum perang dunia ke dua. Nama de stijl sendiri diambil dari nama sebuah majalah seni rupa di Belanda yang sangat terkenal masa itu, karena mengusung konsep-konsep desain pembaharuan dari model dan gaya karya seni rupa masa-masa sebelumnya.

De stijl merupakan aliran arsitektur yang diilhami dari seni lukis. Dalam karya seninya lebih mengutamakan bentuk-bentuk abstract yang lebih sederhana. De Stijl tumbuh bersamaan dengan terjadinya perang dunia. Dimana aliran ini merupakan suatu gabungan kelompok seniman antara pelukis, pematung dan arsitek. Tujuan utama dari aliran ini adalah menyatukan wujudwujud seni menjadi suatu lahan ruang. Pertama kali di wujudkan dalam lukisan-lukisan abstrak seorang pelukis bernama Piet Mondrian. Sumbangan besar di berikan aliran De Stijl, hal ini di lihat dari:

a. Adanya permainan bidang-bidang yang menonjol.

b. Permainan datar.

c. Hubungan antar ruang yang harmonis dan selaras.

d. Fungsionis dan keberlanjutan.

Konsep dasar dari De stijl sendiri menuju kepada bentuk abstrack dan batas-batas jelas dan langsung dari elemen-elemen dari bahasa visual menjadi konsekuensi dalam mewujudkan konsep ke dalam bentuk seni termasuk arsitektur.

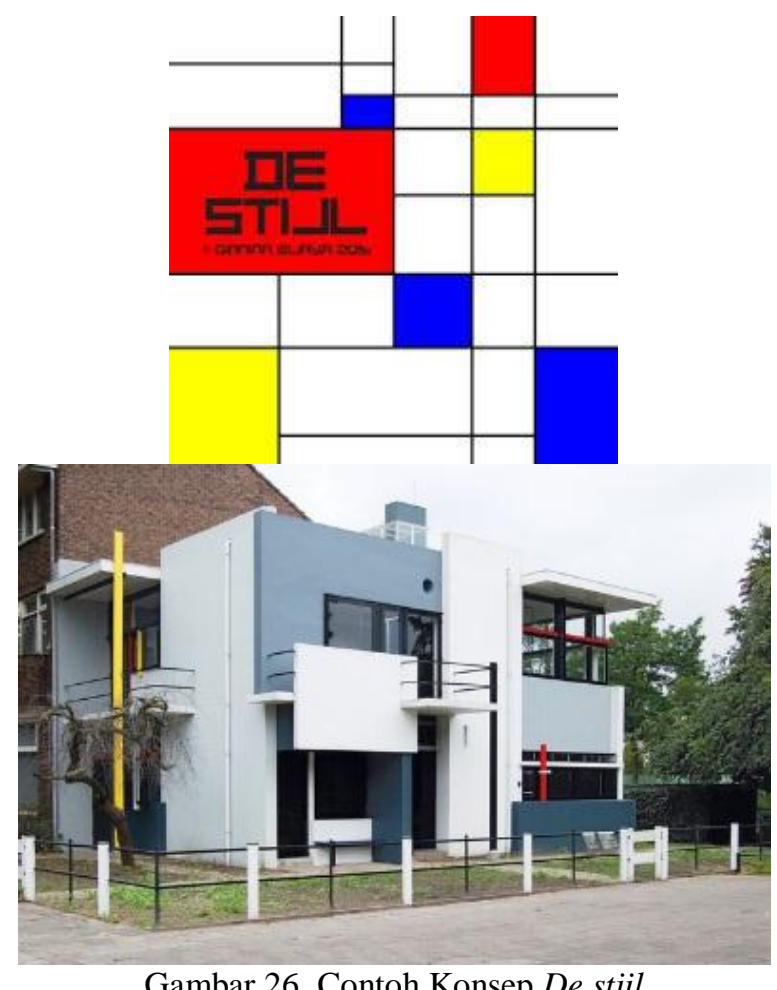

PENUTUP

\section{Simpulan}

Penulis menyimpulkan bahwa tema arsitektur modern aliran de stijl dengan konsep learning, socialization, recreation, perpustakaan dibagi menjadi tiga zona area yaitu ara belajar atau gedung perpustakaan umum, area sosialisasi dibuat fasilitas amphitheater, dan area rekreasi 
seperti wisata perahu, area foto dll, perpustakaan umum terkesan menjadi bersifat sangat terbuka bagi masyarkat. penzoningan area dirancang dengan berbagai pertimbangan dari analisa tapak, bentuk bangunan dirancang dengan metode de stjil penulis merasa ini kebetulan yaitu bangunan sekitar mempunyai ciri-ciri yang hampir sama dengan destjil berdasarkan warna dan bentuk geometri, sehingga dapat dikatakan juga metode yang digunakan adalah konstekstual.

\section{Saran}

Saran dari penulis dalam merancang perpustakaan umum dengan pendekatan arsitektur modern aliran de stjil yaitu berani mengekspor bentuk- bentuk serta elemen-elemen atau langgam-langgam yang sesuai dengan de stjil, sehingga bisa menciptakan suasana fresh, terbuka dan tidak membosankan. Terima kasih.

\section{DAFTAR PUSTAKA}

Neufert, Ernst. 1993. Data Arsitek, jilid I Edisi Kedua, Jakarta : Penerbit Erlangga.

Perpustakaan Nasional RI. 2011. Standar Nasional Perpustakaan.

Blotkamp, Carel. dkk. 1982. De beginjaren van De Stijl 1917-1922. Utrecht: Reflex.

DeChiara, Joseph. 2001. Time Saver Standars For Interior Design And Space Planning. Amerika : Mc Graw- Hill Education.

Edward Hall dalam Laurens (2004: 194)

Mulder, Bertus. 1984, Rietveld scholder huis. Utrecht: Impress.

\section{Website}

" minat baca di kota tangsel hanya 0-001 persen." bantenhits.com. 18 Mei 2018. https://bantenhits.com/2017/05/18/minatbaca-di-kota-tangsel-hanya-0-001persen/.

"mapping perpustakaan" google maps. $>$ https://www.google.com/maps/search/P erpustakaan+Umum/@ $6.3382902,106.6914516,12.75 z<$.

www.Archdaily.com

www.googlemaps.com

https://en.climate-

data.org/asia/indonesia/banten/tangerangselatan-974688/

https://tangerangkota.bps.go.id/dynamictable/201 8/03/26/96/jumlah-penduduk-kotatangerang-2005-2016.html https://www.slideshare.net/joihot/materiteknis-rtrw-tangerang-selatan 